\title{
Occurrence and risk factors for Toxoplasma gondii infection in goats from micro-regions of the state of Piauí
}

\section{Ocorrência e fatores de risco para infecção por Toxoplasma gondii em caprinos de microrregiões do Estado do Piauí}

\author{
Karina Rodrigues dos Santos ${ }^{1}$; Jezlon da Fonseca Lemos²; \\ Carla Duque Lopes ${ }^{3}$; Richard Atila Sousa ${ }^{4}$; \\ Marcelo Richelly Alves de Oliveira ${ }^{5}$; Carlos Syllas Monteiro Luz ${ }^{5 *}$; \\ Severino Cavalcante de Sousa Júnior ${ }^{1}$
}

\begin{abstract}
This study aimed to evaluate the seroprevalence and risk factors associated with Toxoplasma gondii infection in goats from micro-regions of the state of Piauí (Brazil). From six randomly selected properties, 145 goats were examined. Serum samples of the animals were analyzed by ELISA for the presence or absence of antibodies against $T$. gondii. Of these, $22 \%$ were seroreactive for $T$. gondii. Individual records were also taken for each property. These analyses showed that factors such as sex, age, water source, and presence of cats were associated with animal seropositivity. In addition, there was also a positive correlation $(\mathrm{p}>0.04)$ between animal sex and $T$. gondii contamination. The presence of cats in the facilities and animal pasture fields appeared to be a risk factor for the contamination of goats in the assessed properties ( $\mathrm{p}>0.03)$. The parasite Toxoplasma gondii is present in the goat herds of southern Piauí state, and females are more likely to be contaminated.
\end{abstract}

Key words: Goats. Seroprevalence. Piauí. Toxoplasmosis.

\section{Resumo}

Este estudo teve como objetivo avaliar a soroprevalência e os fatores de risco associados a infecção por Toxoplasma gondii em caprinos de microrregiões do Estado do Piaú. Um total de 145 caprinos foram examinados, em seis propriedades selecionadas aleatoriamente. Amostras de soro dos caprinos foram analisadas por ELISA para investigar a presença ou ausência de anticorpos contra T. gondii. Assim, $22 \%$ dos caprinos foram sororeativos para $T$. gondii. Foram realizadas anotações individuais de cada propriedade, sendo observado que fatores como: sexo, idade, origem de água fornecida e presença de gatos foram associados à soropositividade encontrada nos animais, foi obtido correlação positiva $(\mathrm{p}>$ $0,04)$ entre o sexo dos animais e a contaminação por T. gondii. A presença de gatos nas instalações e ao pasto dos animais foi importante para contaminação dos caprinos nas propriedades analisadas ( $\mathrm{p}>$

1 Profs., Curso de Medicina, Universidade Federal do Piauí, UFPI, Campus Ministro Reis Velloso, Parnaíba, PI, Brasil. E-mail: krsantos2004@yahoo.com.br; sevzoo@yahoo.com.br

2 Médico Veterinário, UFPI, Campus Cinobelina Elvas, Bom Jesus, PI, Brasil. E-mail: jezlon.fonseca@hotmail.com

3 Pesquisadora, Departamento de Biologia Celular e Bio Agentes Patogênicos, Faculdade de Medicina de Ribeirão Preto, Universidade de São Paulo, USP, Ribeirão Preto, SP, Brasil. E-mail: cdlopes@usp.br

4 M.e, Ciência Animal, UFPI, Centro de Ciências Agrárias, CCA, Teresina, PI, Brasil. E-mail: richard@ufpi.edu.br

5 Discentes de Doutorado em Ciência Animal, UFPI, Centro de Ciências Agrárias, CCA, Teresina, PI, Brasil. E-mail: marcelozootec@hotmail.com; syllaszoot@yahoo.com.br

* Author for correspondence 
0,03). O Toxoplasma gondii está presente nos rebanhos caprinos do Sul do Estado do Piauí, sendo as fêmeas dos animais analisados, as mais susceptíveis ao parasito.

Palavras-chave: Caprinos. Piauí. Soroprevalência. Toxoplasmose.

\section{Introduction}

Goat rearing in northeastern Brazil has a major importance for the domestic economy, as it holds the largest herd of the country (91.4\%) and makes use of its products and by-products (NOGUEIRA FILHO, 2003). The state of Piauí has the third largest herd of goats in this region (16\%), surpassed only by the states of Bahia (34\%) and Pernambuco (20\%) (IBGE, 2008).

The first evidence of toxoplasmosis in goats was recorded by Feldman and Miller (1956), after examining herds in the state of New York (USA). Since then, various investigations have been carried out, including in Brazil.

In Brazil, the incidence of toxoplasmosis in goat herds is relevant. In south and southeast of the country, the rates average between $36.8 \%$ and $14.5 \%$ (MAINARDI et al., 2003; FIGLIUOLO et al., 2004). Whereas in northeastern states such as Bahia (UZÊDA et al., 2007), Rio Grande do Norte (LIMA et al., 2008), Ceará (CAVALCANTE et al., 2008), and Pernambuco (SILVA et al., 2003), the rates totaled $11.53 \%, 17.1 \%, 25.7 \%$, and $10.33 \%$, respectively. Despite these studies addressing the issue of toxoplasmosis in sheep and goats in these regions, there is still little data for the Northeast region as a whole, and especially for the state of Piauí.

Toxoplasma gondii is the causative agent of toxoplasmosis, a disease that is usually benign in immunocompetent individuals. However, it may be serious or fatal in children with congenital diseases or immunocompromised patients (DUBEY et al., 2012). Infection by this pathogen is commonly found in production animals such as sheep, goats, and pigs, leading to major economic losses through stillbirths, miscarriages, and birth defects (UZÊDA et al., 2007; PEREIRA et al., 2012).

In addition, the transmission of $T$. gondii through food consumption is one of the most important routes of infection in humans (PEREIRA et al., 2010), which happens by intaking of cyst tissue fragments while handling or eating raw or poorly cooked meat. With the worldwide trend of largescale meat production, Toxoplasma contamination has been spread currently to a larger area (JONES; DUBEY, 2012).

The consumption of in nature goat milk and its byproducts also poses risks of contamination for humans, with local cases of public health threats already reported (SIBLEY, 2003). The lack of studies and knowledge by breeders from the northeastern regions entails losses for themselves and hazards of consumption to local populations. In this context, our study is the first to correlate seroprevalence with possible risk factors for $T$. gondii infection and transmission among goat herds within the southern state of Piauí.

Thus, this study aimed to investigate Toxoplasma gondii occurrence in goats from farms in the south of the state of Piauí, collecting epidemiological data and correlating them to toxoplasmosis prevalence.

\section{Material and Methods}

\section{Experiment location}

The study was carried out in six goat breeding farms selected randomly. Among the evaluated properties, four are in towns within the micro-region of Alto-Médio Gurguéia, and two in municipalities within the micro-region of Chapada do Extremo Sul, all in the southern part of Piauí state, Brazil. 


\section{Animals}

Data were cataloged in index cards and arranged by municipality for studies of toxoplasmosis prevalence in farms. Each card contained a questionnaire with information about the property, breeding system, and presence of pets.

\section{Sample collection and storage}

Blood samples of $3 \mathrm{~mL}$ were collected by jugular venous puncture from 145 goats, using 3-mL sterile syringes. The samples were stored in $5-\mathrm{mL}$ sterile vacutainer tubes without anticoagulant kept at room temperature. Then, they were centrifuged at 2000 rpm for 10 minutes at room temperature, at the Laboratory of Clinical Pathology and Parasitology of the Federal University of Piauí (UFPI). The sera obtained were transferred to $1.5-\mathrm{mL}$ Eppendorf tubes properly identified with the number of each animal and stored at $-20^{\circ} \mathrm{C}$. These were sent to the Immunology Laboratory at the Federal University of Uberlandia (UFU) for serological examination.

\section{Enzyme-Linked Immunosorbent Assay (ELISA)}

To detect IgG antibodies against $T$. gondii, an ELISA protocol was used, as previously described by Silva et al. (1997). The serum-conversion of goats was measured using polystyrene plates (INTERLAB, São Paulo, Brazil) previously covered with a $T$. gondii antigen solution (STAg), in sodium carbonate buffer (0.06 M, pH 9.6), similarly to the method by Mineo et al. (1980). After incubation for 18 hours at $4^{\circ} \mathrm{C}$, wells were washed three times with PBST (PBS added to $0.01 \%$ Tween 20) and incubated with the serum samples from positive control animals, in duplicate, diluted 1:32 in PBST plus $0.5 \%$ non-fat dried milk (MOLICO - Nestlé) for 2 hours for TA. The wells were again washed with PBST and incubated with primary anti-goat antibody produced in goats (Abcam) for 1 hour for TA. Subsequently, the wells were washed and incubated with anti-goat antibody complexed with peroxidase (R\&D Systems) for 1 hour at TA. The reaction was followed by the addition of hydrogen peroxide $(0.04 \%)$ and ortho-phenylenediamine $(0.5 \mathrm{mg} / \mathrm{mL})$ diluted in phosphate-citrate buffer (0.1M, pH 5.0). After incubation for 15 minutes at room temperature, the reaction was stopped with $\mathrm{H}_{2} \mathrm{SO}_{4}(2 \mathrm{~N})$. Finally, the values of optical density (OD) were measured at $450 \mathrm{~nm}$ in an ELISA reader (Titertek Multiskan Plus MKII, Flow Laboratories, McLean, USA). The levels of anti- T. gondii antibodies were arbitrarily expressed in ELISA index (EI), according to the formula: $\mathrm{EI}=\mathrm{Abs}$ test sample/ cutoff, where cutoff was calculated as mean OD values of negative control sera plus three standard deviations. Samples with an EI $>1.2$ were considered positive for excluding positive reactivity close to $\mathrm{EI}=1.0$.

This study was developed complying with the guidelines for ethics and biosafety, and under the approval of the Ethics Committee on Animal Use (CEUA) of the Federal University of Piauí - UFPI (n $\left.{ }^{\circ} 0096 / 2010\right)$.

The results were subjected to Chi-square test and considered positive at $(\mathrm{p}<0.5)$. The data were analyzed using the statistical software GraphPad Prism (GraphPad, La Jolla, CA, USA).

\section{Results and Discussion}

Among the 145 goat sera analyzed, 32 (22.07\%) had reactive antibodies to $T$. gondii. Our data are consistent with those found in other Brazilian regions. In Pernambuco, Pereira et al. (2012) analyzed 167 sera samples of goats, of which 53 (31.8\%) presented antibodies against the parasite. In Rio de Janeiro, Luciano et al. (2011) observed a total of $29.12 \%$ seropositive, while Mainardi et al. (2003) and Lima et al. (2008) found seroprevalence of $14.47 \%$ and $17.1 \%$, respectively, in the state of São Paulo. In Ceará state, samples of goats, assessed by ELISA test, demonstrated that 25.1\% of the goats were positive (CAVALCANTE et al., 2008). In our study, the flocks of the six evaluated 
municipalities had animals contaminated by the parasite, demonstrating its disseminated throughout the south region of Piauí state. According to Table 1 , the city that stood out with the highest number of seropositive goats for $T$. gondii was Redenção do Gurguéia, followed by Currais, Bom Jesus, and Júlio Borges.

Table 1. Seropositive and seronegative samples for $T$. gondii of goats from the towns of Alto Médio Gurguéia and Chapada do Extremo Sul, in the southern state of Piauí (Brazil), during November and December 2011.

\begin{tabular}{lccc}
\hline \multirow{2}{*}{ Town } & Number of samples & \multicolumn{2}{c}{ ELISA } \\
\cline { 3 - 4 } Bom Jesus & 28 & Reagent (\%) & Non-Reagent (\%) \\
Curimatá & 29 & $8(29)$ & $20(71)$ \\
Currais & 12 & $1(4)$ & $28(96)$ \\
Júlio Borges & 29 & $5(42)$ & $7(58)$ \\
Redenção do Gurguéia & 17 & $6(21)$ & $23(79)$ \\
Santa Luz & 30 & $11(65)$ & $6(35)$ \\
\hline
\end{tabular}

Upon analyzing the physical characteristics of goats, we observed a positive correlation $(p<0.04)$ between the sex of animals and contamination by T. gondii (Table 2). Interestingly, if compared to males, females had a higher number of positive antibodies, confirming the findings of Uzêda et al. (2007), who related the susceptibility of females to a possible immunosuppression during pregnancy and lactation. Reports in the literature correlate the age of goats to a prolonged exposure to parasites. Uzêda et al. (2007) described that in goats aged from 4 to 6 years have an increased serum-reactivity towards T. gondii if compared to younger animals. In the present study, the small age variation of animals (1 to 3 years) prevented us to correlate goat age with parasite contamination.

The water supplied to the flocks constituted a risk factor for the spread and contamination by T. gondii. Romanelli et al. (2007) and Luciano et al. (2011) found a higher infection rate in goats provided with water from weirs $(46.11 \%)$, followed by those consuming water from wells (44.61\%) and other water sources $(24.22 \%)$. The contamination by these sources is probably due to the presence of many seropositive animals (domestic or wild felids), which spread oocysts near these sources. However, our data showed that neither water from springs nor wells were risky for toxoplasmosis.

Cats are key hosts keys for the life cycle of $T$. gondii, being the only ones able to host the sexual form of the parasite (DUBEY et al., 1998). As expected, the presence of cats, with free access to the facilities and pasture, was relevant for the contamination of goats in the analyzed farms ( $p$ $<0.03$ ). Other studies have already made this association (ROMANELLI et al., 2007; ARAUJO NETO et al., 2008; GARCIA, 2010). Therefore, it is a prominent risk factor for infection by Toxoplasma since oocytes in the feces of cats can remain infectious for several months to years in the environment depending on the environmental conditions (OGAWA et al., 2003). Given the importance of consumption of goat products and byproducts in northeastern Brazil, our findings point to further risks of the spread of infections between goat flocks and/or to other animals within the region, but more importantly, warning for contamination of local people. 
Table 2. Correlation between presence of antibodies against $T$. gondii with environmental and goat characteristics, in the southern state of Piauí, Brazil.

\begin{tabular}{|c|c|c|c|c|c|}
\hline \multirow[b]{2}{*}{ Variable } & & \multicolumn{2}{|c|}{ ELISA } & \multirow{2}{*}{ Sera tested } & \multirow{2}{*}{ Statistics } \\
\hline & & Reagent (\%) & Non-reagent (\%) & & \\
\hline \multirow{3}{*}{ Sex } & Male & $3(9.4 \%)$ & $29(87.6 \%)$ & $32(22.1 \%)$ & \multirow{3}{*}{$\begin{array}{c}X^{2}=3.847 \\
p=0.0498\end{array}$} \\
\hline & Female & $29(25.7 \%)$ & $84(74.3 \%)$ & $113(77.9 \%)$ & \\
\hline & Total & $32(22.1 \%)$ & $113(77.9 \%)$ & 145 & \\
\hline \multirow{3}{*}{ Age } & From 1 to 2 years & $12(17.1 \%)$ & $58(82.9 \%)$ & $70(48.3 \%)$ & \multirow{3}{*}{$\begin{array}{l}X^{2}=1.910 \\
p=0.1670\end{array}$} \\
\hline & From 1 to 3 years & $20(26.7 \%)$ & $55(73.3 \%)$ & $75(51.7 \%)$ & \\
\hline & Total & $32(22.1 \%)$ & $113(77.9 \%)$ & 145 & \\
\hline \multirow{3}{*}{ Water source } & Spring & $5(41.7 \%)$ & $7(58.3 \%)$ & $12(8.3 \%)$ & \multirow{3}{*}{$\begin{array}{l}X^{2}=2.922 \\
p=0.0874\end{array}$} \\
\hline & Artesian Well & $27(20.3 \%)$ & $106(79.7 \%)$ & $133(91.7 \%)$ & \\
\hline & Total & $32(22.1 \%)$ & $133(77.9 \%)$ & 145 & \\
\hline \multirow{3}{*}{ Presence of cats } & Presence & $17(37 \%)$ & $29(63 \%)$ & $46(31.7 \%)$ & \multirow{3}{*}{$\begin{array}{l}X^{2}=8.683 \\
p=0.032\end{array}$} \\
\hline & Absence & $15(15.2 \%)$ & $84(84.8 \%)$ & $99(68.3 \%)$ & \\
\hline & Total & $32(22.1 \%)$ & $113(77.9 \%)$ & 145 & \\
\hline
\end{tabular}

\section{Conclusion}

Toxoplasma gondii is present in the goat herds located in the southern Piauí state, where the majority of cases was observed in the micro-region of Alto Medio Gurguéia. Goat females are more susceptible to infection than males. Cats contribute to the increasing incidence of Toxoplasma gondii in breeding animals. Adult animals are the most susceptible to toxoplasma infection.

\section{Acknowledgments}

We thank Dra. Maria Cristina Roque-Barreira for material and support for this study, and the Laboratory of Cell Biology and Pathogenic Bioagents of the University of São Paulo - USP (Ribeirão Preto- SP, Brazil).

\section{References}

CAVALCANTE, A. C. R.; CARNEIRO, M.; GOUVEIA, A. M. G.; PINHEIRO, R. R.; VITOR, R.W.A. Risk factors for infection by Toxoplasma gondii in herds of goats in Ceará, Brazil. Arquivos Brasileiros de Medicina Veterinária e Zootecnia, Belo Horizonte, v. 60, n. 1, p. 36-41, 2008. Available at: <http://dx.doi. org/10.1590/ S0102-09352008000100006>. Accessed at: out. 20, 2017.

DUBEY, J. P.; LINDSAY, D. S.; SPEER, C. A. Structures of Toxoplasma gondii tachyzoites, bradyzoites, and sporozoites and biology and development of tissue cysts. Clinical Microbiology Reviews, Washington, v. 11, n. 2, p. 267-299, 1998. Available at: < https://www.ncbi.nlm. nih.gov/pubmed/29848775>. Accessed at: out. 20, 2017.

DUBEY, J. P.; LAGO, E. G.; GENNARI, S. M.; SU, C.; JONES, J. L. Toxoplasmosis in humans and animals in Brazil: high prevalence, high burden of disease, and epidemiology. Parasitology, Cambridge, v. 139, n. 11, p. 1375-1424, 2012. Available at: <https://www.ncbi.nlm. nih.gov/pubmed/22776427>. Accessed at: jul. 10, 2017.

FELDMAN, H.; MILLER, L. T. Sorological study of toxoplasmosis prevalence. American Journal of Hygiene, Baltimore, v. 64, n. 3, p. 320, 1956. Available at: $<$ https:// www.cabdirect.org/cabdirect/abstract/ 19572901424>. Accessed at: jul. 10, 2012.

FIGLIUOLO, L. P.; KASAI, N.; RAGOZO, A. M.; PAULA, V. S. de; DIAS, R. A.; SOUZA, S. L.; GENNARI, S. M. Prevalence of anti-Toxoplasma gondii 
and anti-Neosporacaninum antibodies in sheep from São Paulo State, Brazil. Parasitologia Veterinária, São Paulo, v. 123 n. 3 p. 161-166, 2004. Available at: < http://dx.doi. org/10.1590/1808>. Accessed at: jan. 12, 2016.

GARCIA, G. Soroepidemiologia da toxoplasmose caprina na Mesorregião Metropolitana de Curitiba, Paraná, Brasil. 2010. Dissertação (Mestrado em Microbiologia, Parasitologia e Patologia) - Setor de Ciências Biológicas e da Saúde. Universidade Federal do Paraná, Curitiba, PR.

INSTITUTO BRASILEIRO DE GEOGRAFIA E ESTATÍSTICA - IBGE. Pesquisa Pecuária Censo Agropecuário Municipal. 2008. Available at: <http:// www.ibge.gov.br/estadosat/temas.pecuaria.2008>. Accessed at: mar. 18, 2015.

JONES, J. L.; DUBEY, J. P. Food borne toxoplasmosis. Clinical Infection Diseases, Oxford, v. 55, n. 6, p. 845851, 2012. Available at: $<$ https://doi.org/10.1093/cid/ cis508>. Accessed at: jan. 12, 2016.

LIMA, J. T. R.; AHID, S. M. M.; BARRÊTO JÚNIOR, R. A.; PENA, H. F. J.; DIAS, R. A.; GENNARI, S. M. Prevalência de anticorpos anti-Toxoplasma gondii e antiNeospora caninum em rebanhos caprinos do município de Mossoró, Rio Grande do Norte. Brazilian Journal of Veterinary Research and Animal Science, São Paulo, v. 45, n. 2, p. 81-86, 2008. Available at: <https://www. revistas.ufg.br/vet/article/view/7884/ 5720>. Accessed at: jan. 12, 2016.

LUCIANO, D. M.; MENEZES, R. C.; FERREIRA, L. C.; NICOLAU, J. L.; NEVES, L. B.; LUCIANO. R. M.; DAHROUG, M. A. A.; AMENDOEIRA, M. R. R. Soroepidemiologia da toxoplasmose em caprinos e ovinos de três municípios do Estado do Rio de Janeiro. Pesquisa Veterinária Brasileira, São Paulo, v. 31, n. 7, p. 569-574, 2011. Available at: <http://dx.doi.org/10.1590/ S0100-736X2011000700004>. Accessed at: jan. 12, 2016.

MAINARDI, R. S.; MODOLO, J. R.; STACHISSINI, A. V. M.; PADOVANI, C. R.; LANGONI, H. Soroprevalência de Toxoplasma gondii em rebanhos caprinos no Estado de São Paulo. Revista da Sociedade Brasileira de Medicina Tropical, Uberaba, v. 36, n. 6, p. 759-761, 2003. Available at: < http://dx.doi.org/ 10.1590/ S0037>. Accessed at: mar. 12, 2017.

MINEO, J. R.; CAMARGO, M. E.; FERREIRA, A. W. Enzyme-linked immunosorbent assay for antibodies to Toxoplasma gondii polisaccharide in human toxoplasmosis. Infection and Immunity, Washington, v. 27, n. 2, p. 283-287, 1980. Available at: <https://www. ncbi.nlm.nih.gov/pmc/articles/PMC550761/>. Accessed at: apr. 8, 2018.
ARAUJO NETO, J. O.; AZEVEDO, S. S.; GENNARI, S. M.; FUNADA, M. R.; PENA, H. F.; ARAÚJO, A. R.; BATISTA, C. S.; SILVA, M. L.; GOMES, A. A.; PIATTI, R. M.; ALVES, C. J. Prevalence and risk factors for anti-Toxoplasma gondii antibodies in goats of the Seridó Oriental microregion, Rio Grande do Norte state, Northeast region of Brazil. Veterinary Parasitology, Liverpool, v. 156, n. 3-4, p. 329-332, 2008. Available at: $<$ https://www.ncbi.nlm.nih.gov/pubmed/18583058>. Accessed at: mar. 12, 2017.

NOGUEIRA FILHO, A. Ações de fomento do banco do Nordeste e potencialidades da caprino-ovinocultura. In: SIMPÓSIO INTERNACIONAL SOBRE CAPRINOS E OVINOS DE CORTE, 1., 2003, João Pessoa. Anais... EMEPA-PB: EMEPA, 2003. p.43-55,

OGAWA, L.; NAVARRO, I. T.; FREIRE, R. L.; OLIVEIRA, R. C.; VIDOTTO, O. Ocorrência de anticorpos anti-Toxoplasma gondii em ovinos da região de Londrina no Estado do Paraná. Semina: Ciências Agrárias. Londrina, v. 24, n. 1, p. 57-62, 2003. Available at: $<$ http://dx.doi.org/10.4322/rbpv.018e1013>. Accessed at: set. $12,2017$.

PEREIRA, K. S.; FRANCO, R. M.; LEAL, D. A. Transmission of toxoplasmosis (Toxoplasma gondii) by foods. Advances in Food and Nutrition Research, San Diego, v. 60, p. 1-19, 2010. Available at: <https://www. ncbi.nlm.nih.gov/pubmed/20691951>. Accessed at: ago. 12, 2017.

PEREIRA, M. F. PEIXOTO, R. M.; LANGONI, H.; GRECA JUNIOR, H.; AZEVEDO, S. S.; PORTO, W. J. N.; MEDEIROS, E. S.; MOTA, R. A. Fatores de risco associados à infecção por Toxoplasma gondii em ovinos e caprinos no estado de Pernambuco. Pesquisa Veterinária Brasileira. São Paulo, v. 32, n. 2, p. 140-146, 2012. Available at: <http://dx.doi.org/10.1590/S0100736X2012000200009>. Accessed at: ago. 12, 2017.

ROMANELLI, P. R.; FREIRE, R.L.; VIDOTTO, O.; MARANA, E. R.; OGAWA, L.; PAULA, V. S. de; GARCIA, J. L.; NAVARRO, I. T. Prevalence of Neospora caninum and Toxoplasma gondii in sheep and dogs from Guarapuava farms, Paraná State, Brazil. Research Veterinary Science, Oxford, v. 82, p. 202-207, 2007. Available at: <https://www.ncbi.nlm.nih.gov/ pubmed/17266999>. Accessed at: ago. 12, 2017.

SIBLEY, L. D. Recent origins among ancient parasites. Veterinary Parasitology, Liverpool, v. 115, p. 185-198, 2003. Available at: <https://www.ncbi.nlm.nih.gov/ pubmed/17266999>. Accessed at: jul. 15, 2017.

SILVA, A. V.; CUNHA, E. L. P.; MEIRELES, L. R.; GOTTSCHALK, S.; MOTA, R. A.; LANGONI, H. Toxoplasmose em ovinos e caprinos: estudo 
soroepidemiológico em duas regiões do Estado de Pernambuco, Brasil. Ciência Rural, Santa Maria, v. 33, n. 1, p. 115-119, 2003. Available at: <http://dx.doi.org/ 10.1590/S0103-84782003000100018>. Accessed at: maio $13,2017$.

SILVA, D.A. O.; CABRAL, D. D.; BERNARDINA, B. L.; SOUZA, M. A.; MINEO, J. R. Detection of Toxoplasma gondii-specific antibodies in dogs. A comparative study of immunoenzymatic, immunofluorescent and haemagglutination titers. Memórias do Instituto Oswaldo Cruz, Rio de Janeiro, v. 92, n. 6, p. 98-100, 1997.

UZÊDA, R. S.; PINHEIRO, A. M.; FERNÁNDEZ, S. Y.; AYRES, M. C. C.; GONDIM, L. F. P.; ALMEIDA, M. A. O. Seroprevalence of Neosporacaninum in dairy goats from Bahia, Brazil. Small Ruminant Research, Wilmington, v. 70, n. 2-3, p. 257-259, 2007. Available at: <http://repositorio.ufba.br/ri/ handle/ri/14418>. Accessed at: jun. 17, 2017. 
